\title{
KEMAMPUAN GURU TAMAN KANAK-KANAK DI YOGYAKARTA DALAM MENGEMBANGKAN TEMA PEMBELAJARAN BERBASIS BUDAYA LOKAL
}

\author{
Ika Budi Maryatun, Joko Pamungkas, dan Martha Christianti \\ Universitas Negeri Yogyakarta \\ Email: ika_budimaryatun@uny.ac.id
}

\begin{abstract}
Abstrak
Artikel ini berisi hasil penelitian tahap awal tentang pengetahuan dan pemahaman guru Taman Kanak-kanak tentang pengembangan tema pembelajaran berbasis budaya lokal. Metode penelitian yang digunakan adalah kualitatif. Data dikumpulkan menggunakan teknik wawancara, dan dokumentasi. Jumlah guru sampel penelitian adalah 70 orang guru TK se Yogyakarta. Hasil penelitian menunjukkan bahwa 91,5 persen guru belum mengembangkan tema pembelajaran berbasis budaya lokal. Salah satu kendala yang dihadapi adalah tidak ada pelatihan khusus untuk mengembangkan tema pembelajaran berbasis budaya lokal tersebut. Hasil penelitian ini mendorong peneliti untuk melakukan penelitian lanjutan terkait pengembangan tema pembelajaran berbasis budaya lokal dalam bentuk desain pengembangan tema pembelajaran berbasis budaya lokal, ujicoba, dan diseminasi produk.
\end{abstract}

Kata kunci: kemampuan guru, pengembangan tema, budaya lokal

\section{THE ABILITY OF YOGYAKARTA KINDERGARTEN TEACHER TO DEVELOP LEARNING THEME BASED LOCAL CULTURE}

\begin{abstract}
This article contains preliminary research results on knowledge and understanding of teacher kindergarten about learning theme based local culture. Qualitative method used in this research. Data were collected using interview techniques, and documentation. The number of research sample is 70 kindergarten teachers in Yogyakarta. The results show that 91.5 percent of Yogyakarta kindergarten teachers have not developed a local culture-based learning theme yet today. One of the obstacles faced is there is no specific training to develop the learning theme based of local culture.
\end{abstract}

Keywords: teacher ability, learning theme, local culture

\section{PENDAHULUAN}

Budaya adalah satu tema yang menarik untuk dikembangkan dalam pembelajaran (Jackman, 2012:67). Anakanak dapat belajar melalui budaya, belajar dengan budaya, dan belajar menggunakan budaya (Brewer, 2007:34). Namun di sisi lain sebagian ilmu tentang budaya bersifat abstrak yang sulit dipahami dan diberikan dalam kegiatan bermain anak usia dini (Crain, 2007:89). Pengemasan budaya yang akan digunakan sebagai bahan ataupun media pembelajaran sebaiknya merunut pada latar belakang, usia, maupun pengalaman anak terlebih dahulu (Papalia, et al., 2008:42). Semua ini dapat dilakukan dengan cara mempelajari individu per anak sehingga budaya yang diberikan sebagai materi maupun media pembelajaran PAUD dapat bermakna.

Anak dapat belajar budaya melalui tujuh unsur budaya yang ada, yaitu sistem religi dan upacara keagamaan, sistem dan organisasi kemasyarakatan, sistem pengetahuan, bahasa, kesenian, sistem mata pencaharian hidup, dan sistem teknologi dan peralatan (Koentjaraningrat, 1997:19). Ketujuh unsur budaya ini dapat dijadikan materi maupun bahan kegiatan main anak usia dini dengan memilah unsur 
yang dapat diberikan secara konkret terlebih dahulu. Guru perlu mendalami referensi budaya dengan baik agar konsep budaya yang akan ditanamkan tidak melenceng dari makna sesungguhnya. Wawasan guru mengenai budaya setempat akan menambah kompetensi pedagogiknya dalam membuat perencanaan pembelajaran (Suyanto, 2005:40).

Kompetensi pedagogik guru PAUD salah satunya adalah merancang pembelajaran yang akan digunakan sebagai acuan dalam melaksanakan pembelajaran di kelas. Kemampuan merencanakan pembelajaran model tematik diawali dengan kemampuan memilih topik yang akan digunakan sebagai tema pembelajaran untuk kemudian mengembangkannya menjadi topik ataupun tema harian (Rusman, 2012:34). Salah satu topik menarik yang dapat dipilih guru adalah budaya yang dapat dikembangkan menjadi tema harian agar anak dapat memaknai budaya tidak sekedar secara ritual melainkan juga melekat dalam diri dan perilaku anak. Budaya yang dikembangkan menjadi tema harus mampu menyatukan berbagai materi pengembangan dari berbagai aspek yang dimiliki anak secara utuh karenanya budaya dapat diangkat dalam pembelajaran tematik agar pembelajaran tidak terpisahpisah.

Model pembelajaran tematik merupakan model pembelajaran yang digunakan di Taman Kanak-kanak. Tematik berarti bahwa strategi pembelajaran yang melibatkan beberapa bidang pengembangan untuk memberikan pengalaman yang bermakna kepada anak (Nurani, 2013:27). Pembelajaran yang dilaksanakan secara tematik dilaksanakan mengacu pada satu topik dalam sehari pembelajaran atau lebih. Kegiatan yang dilakukan lebih terarah dan guru dapat fokus melakukan stimulasi perkembangan anak menggunakan satu topik saja setiap harinya. Pembelajaran tematik yang mendalam memungkinkan penguasaan konsep suatu pengetahuan dengan tuntas.

Dalam pembelajaran tematik, tema merupakan pengait antar aspek yang dikembangkan. Untuk itu, penting bagi guru untuk memahami tema-tema yang dipilih mengacu pada prinsip pemilihan tema di taman kanak-kanak. Kurikulum 2013 sudah menjabarkan prinsip pemilihan tema di Taman Kanak-kanak secara umum, antara lain kedekatan, kesederhanaan, kemenarikan, dan keinsidentalan (Suyanto, 2008:43). Menganut prinsip pemilihan tema yang ada, guru dapat melakukan pemilahan terhadap tujuh unsur budaya yang akan digunakannya dalam pembelajaran. Namun demikian, tidak semua unsur budaya dapat diangkat menjadi topik pembelajaran.

Pengembangan tema berbasis budaya lokal merupakan target penelitian multitahun yang akan dilakukan oleh peneliti. Langkah awal dalam penelitian ini adalah melakukan analisis kebutuhan terkait dengan pengetahuan guru terhadap kemampuannya mengembangkan tema pembelajaran berbasis budaya lokal. Untuk itu, artikel ini berisi tahap awal penelitian yaitu identifikasi kemampuan guru dalam mengembangkan tema pembelajaran berbasis budaya lokal.

\section{Pengertian Pendidik PAUD}

Pendidik anak usia dini memiliki persamaan definisi dengan guru anak usia dini, yaitu orang yang bekerja dengan anak usia dini yang mendapatkan pelatihan secara professional (Essa, 2003:24). Sementara Feeney mendefinisikan guru sebagai orang yang terlibat dalam pengasuhan dan pendidikan anak usia dini yang memiliki pendidikan anak usia dini dan bekerja dengan anak usia $2-8$ tahun di sekolah maupun di penitipan anak (Feeney, Christensen \& Moravcik, 2006:53). Definisi tersebut mengandung makna bahwa seseorang dikatakan sebagai guru jika ia sudah mendapat pelatihan secara profesional. Sementara guru anak usia dini adalah guru yang bekerja dengan anak dan haruslah orang yang telah mendapatkan pelatihan secara profesional, baik formal maupun non formal.

Makna guru atau pendidik anak usia 
dini juga sudah diatur dalam peraturan menteri pendidikan dan kebudayaan No. 137 Tahun 2014 sebagai tenaga profesional yang bertugas merencanakan, melaksanakan pembelajaran, dan menilai hasil pembelajaran serta melakukan pembimbingan, pelatihan, pengasuhan, dan perlindungan. Pemerintah telah mengatur bahwa untuk menjadi seorang guru dibutuhkan keterampilan profesional untuk mendukung tugasnya. Keprofesionalan ini bisa diperoleh melalui pelatihan dan pengalaman. Guru perlu mengembangkan wawasannya guna menambah profesionalisme secara formal maupun non formal.

Seorang guru dalam melaksanakan tugasnya dibantu oleh tenaga lain yang disebut sebagai caregiver (pengasuh). Pengasuh adalah orang yang bekerja di lembaga PAUD untuk menjaga anak secara fisik dan psikis, sementara guru melakukan tugasnya sebagai pendidik dan pengajar (Essa, 2003:67). Di sisi lain Feeney mendefinisikan pengasuh adalah orang bekerja dengan anak usia kurang dari 2 tahun (bayi dan batita) di penitipan anak (Feeney, Christensen \& Moravcik, 2006:87). Jadi dapat dikatakan bahwa pengasuh adalah orang yang membantu kelancaran tugas guru, terutama ditujukan bagi orang terlibat langsung dengan pendidikan dan pengasuhan bayi dan batita di penitipan anak.

Permendikbud No. 137 Tahun 2014 mengatur bahwa pendidik PAUD terdiri atas guru PAUD, guru pendmping, dan guru pendamping muda. Masing-masing pendidik memiliki kualifikasi tertentu yang diatur dengan peraturan menteri ini. Kompetensi yang perlu dimiliki oleh pendidik PAUD bertujuan untuk memenuhi standar pendidik profesional.

\section{Standar Pendidik PAUD}

National Association for the Education of Young Children (NAEYC) mengeluarkan standar pendidik profesional antara lain (Feeney, Christensen \& Moravcik, 2006:67):
1. Standar 1: Mendukung perkembangan dan pembelajaran anak

Standar 1 ini menganjurkan bahwa seorang guru PAUD perlu memahami kebutuhan dan karakteristik anak didiknya yang berbeda satu dengan lainnya. Guru PAUD juga perlu memiliki keterampilan untuk menciptakan lingkungan pembelajaran yang sehat, saling menghormati, suportif, dan menantang untuk anak sehingga mampu mendukung perkembangan dan pembelajaran anak usia dini. Kegiatan yang sesuai dengan perkembangan anak, latar belakang anak, dan bervariasi mutlak dibutuhkan pada seting PAUD. Contoh implementasi standar 1 ini adalah menciptakan kelas menggunakan sentra ataupun area yang beragam.

2. Standar 2: Membangun hubungan dengan keluarga dan lingkungannya

Standar 2 bermakna bahwa seorang guru PAUD perlu memiliki wawasan tentang keluarga dan latar belakang anak yang beragam. Dengan mengetahui latar belakang anak, guru akan memperlakukan anak sesuai dengan keluarga dan latar belakangnya, tidak menyamaratakannya. Anak membawa kebiasaan adat dan istiadat dalam keluarga maupun lingkungannya ke dalam pembelajaran di sekolah. Guru perlu memperhatikan hal ini agar pembelajaran tidak kontra produktif dengan latar belakang dan pengalaman yang dibawa anak dari rumah. Implementasi standar 2 ini adalah adanya program pertemuan orang tua (parenting) yang rutin di sekolah.

3. Standar 3: Mengamati, mendokumentasikan, dan melakukan asesmen pada kegiatan anak

Standar 3 berarti bahwa seorang guru PAUD perlu memiliki pengetahuan tentang tujuan, manfaat, dan kegunaan asesmen. Guru juga perlu memiliki pengetahuan tentang manfaat observasi, dokumentasi, dan strategi asesmen yang efektif untuk menstimulasi berbagai perkembangan anak. Hasil dari pengamatan, pendokumentasian, dan asesmen dapat digunakan guru untuk 
merancang pembelajaran selanjutnya serta mengevaluasi praktik pembelajaran yang telah dilakukannya guna memperkaya strategi pembelajaran dan mengatasi permasalahan yang dihadapi guru ketika melaksanakan pembelajaran. Implementasinya adalah guru membuat perencanaan, melaksanakan pembelajaran, dan melakukan penilaian terhadap anak selama proses pembelajaran secara otentik. 4. Standar 4: Melaksanakan pembelajaran Standar 4 ini bermakna bahwa guru perlu menguasai berbagai pendekatan dan strategi dalam pembelajaran sehingga kegiatan pengembangan yang dilakukannya tepat sasaran. Guru PAUD perlu terus menggali pengetahuan guna menemukan strategi dan pendekatan pembelajaran yang sesuai dengan karaktersitik kelasnya. Standar 4 ini memiliki 4 sub standar, yaitu:

a. Menciptakan hubungan positif dengan anak dan keluarganya sebagai dasar untuk melaksanakan interaksi positif di antara guru dan anak.

b. Menggunakan pendekatan pembelajaran yang efektif untuk menciptakan pengaruh positif dalam pembelajaran.

c. Memahami konsep pengetahuan masing-masing area perkembangan dalam pembelajaran anak usia dini agar stimulasi aspek perkembangan anak sesuai tujuannya.

d. Mencipatakan kurikulum yang bermakna untuk terciptanya perkembangan anak yang positif.

\section{Standar 5: Menjadi Profesional}

Standar 5 bermakna bahwa guru PAUD harus menjadi pendidik profesional dengan terus menambah wawasan melalui berbagai pelatihan dan bergabung dengan organisasi profesional. Hal ini bertujuan untuk selalu menemukan strategi baru dalam mengajar, mengevaluasi praktik pembelajaran yang telah dilakukannya, dan dapat memecahkan permasalahan pembelajaran bersama komunitas seprofesinya. Implementasi dari standar ini adalah guru perlu bergabung dengan IGTKI maupun Himpaudi.

\section{Tahap Perkembangan Pendidik PAUD}

Pendidik PAUD terus berkembang mengikuti permasalahan di mana ia berkecimpung di dunia pendidikan anak serta pengalaman yang telah diperolehnya. Perkembangan guru per tahap dapat dijabarkan sebagai berikut (Essa, 2003:45).

\section{Tahap 1. Survival}

Tahap survival adalah tahap awal seseorang menjadi guru. Biasanya terjadi pada awal-awal masa kerja seorang guru. Tahap ini dicirikan dengan pemikiran guru yang masih bertanya-tanya, apakah dapat bertahan sebagai guru atau tidak sebagai pemula. Guru yang berada di tahap awal juga menghadapi kegelisahan karena sering mendapati adanya kesenjangan antara teori di bangku kuliah dengan kenyataan yang dihadapinya di lapangan kerja. Perilaku positif diperlihatkan oleh guru tahap awal ini, yaitu selalu melakukan perencanaan yang idealis. Hal ini membutuhkan dukungan, dorongan, dan bimbingan dari guru senior agar idealismenya dapat bertahan. Namun jika guru senior tidak mendukung, ada dua hal yang akan terjadi. Pertama, kemungkinan guru tersebut akan berhenti menjabat sebagai guru karena idealismenya bertentangan dengan kenyataan. Kedua, guru mulai terbawa kebiasaan yang telah ada di sekolah, termasuk kebiasaan negatif.

\section{Tahap 2. Konsolidasi}

Tahap kedua ini guru sudah memiliki kepercayaan diri karena sanggup bertahan sebagai guru. Guru tahap konsolidasi mulai fokus pada tugas-tugasnya yang khusus, seperti pada perkembangan anak satu per satu, tidak lagi sekedar pembelajarannya. Tahap konsolidasi membutuhkan pengetahuan untuk mengembangkan profesinya melalui berbagai pelatihan. Berbagai pelatihan yang mendukung dapat memberikan wawasan pada guru untuk mencari berbagai strategi yang bervariasi dalam pembelajarannya sehingga tidak 
monoton serta mengatasi berbagai masalah yang dihadapinya ketika berhadapan dengan anak.

\section{Tahap 3. Pembaruan}

Tahap pembaruan biasanya terjadi pada guru yang telah mengajar selama tiga atau empat tahun. Tahap ini guru mulai mencari pembaruan pendekatan pembelajaran karena kebosanan mereka terhadap pendekatan yang telah dipraktikkannya pada tahun-tahun sebelumnya. Guru yang berada di tahap ini biasanya inovatif dalam pembelajaran karena selalu mencari hal baru untuk mendukung praktik pembelajaran yang dilakukannya. Pembaruan ilmu pada tahap ini dilakukan melalui diskusi dengan teman sejawat, organisasi profesi, konferensi, buku, jurnal, maupun studi banding.

\section{Tahap 4. Matang}

Tahap akhir dari profesi seorang guru adalah matang. Kematangan seorang guru dicapai pada masa kerja yang berbeda. Artinya tidak semua guru di atas 5 tahun masa kerja akan otomatis mengalami kematangan. Guru yang berada di tahap matang sudah memiliki keterikatan yang kuat dengan profesinya. Atau dengan kata lain guru sudah menjiwai sebagai seorang guru.

\section{Taman Kanak-Kanak}

Peraturan Menteri Pendidikan Indonesia mengatur bahwa yang disebut Taman Kanak-kanak (TK) adalah layanan PAUD diperuntukkan bagi anak usia 4-6 tahun. Sementara Brewer menjabarkan bahwa Taman Kanak-kanak adalah lembaga sekolah yang diperuntukkan bagi anak usia $4-6$ tahun dengan karakteristik dan kebutuhannya sendiri (Brewer, 2007:64). Jadi Taman Kanak-kanak (TK) adalah layanan pendidikan bagi anak yang berada pada rentang usia 4 hingga 6 tahun dengan berbagai karakteristiknya.

Taman Kanak-kanak bukanlah lembaga yang menyiapkan anak untuk memasuki sekolah dasar. TK sesuai hasil deklarasi dasar memiliki tujuan untuk membantu anak belajar sepanjang hayat. Pengertian ini mengandung makna bahwa pendidikan sepanjang hayat tidak bertujuan utama untuk menghasilkan anak yang terampil calistung, tetapi lebih pada memberikan pembiasaan perilaku. Hal ini dapat dilihat dari gambar 1 berikut.

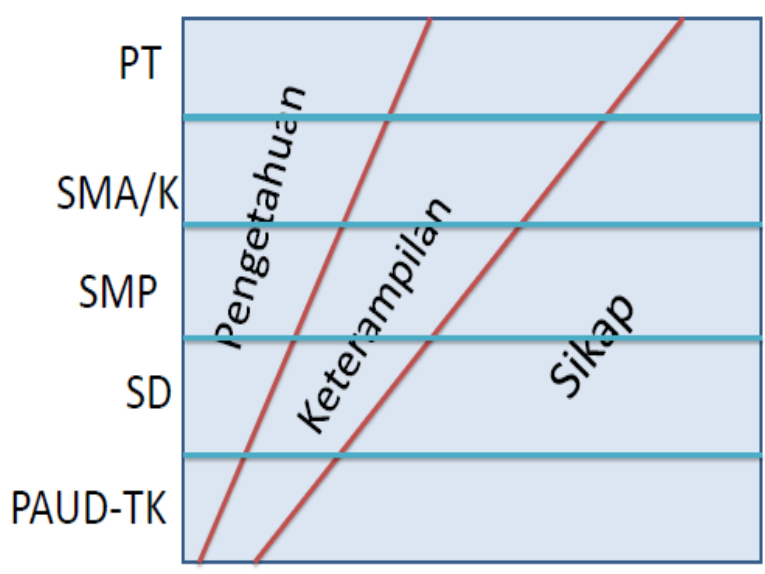

Sumber: Kemendikbud 2014b

\section{Gambar 1. Tujuan Pembelajaran Tiap Jenjang Pendidikan}

Gambar 1 di atas menjelaskan bahwa fokus pengembangan PAUD, termasuk di dalamnya TK, adalah mengembangkan sikap anak agar menjadi sebuah perilaku pada anak. Sikap dikembangkan di TK melalui berbagai pembiasaan yang diintegrasikan dalam berbagai aktivitas anak. Sikap terbentuk melalui berbagai kegiatan yang dilakukan secara bertahap dan berulang sesuai karaktersitik anak TK.

\section{Tema Pembelajaran}

Guru melaksanakan pembelajaran akan lebih sistematis jika ia menggunakan tema sebagai pemersatu berbagai kegiatan yang disusunnya. Tema dalam Permendikbud No. 137 Tahun 2014 merupakan sajian lingkup materi dari standar isi kurikulum. Tema ini dijadikan sarana pemersatu atau penghubung kegiatan selama satu hari (Nurani, 2013:22). Tema merupakan topik tentang segala hal di sekitar yang bersifat luas, seperti diri sendiri, lingkungan, teman, ataupun musim (Jackman, 2012:162). 
Tema sendiri memiliki manfaat dalam pembelajaran sebagai berikut (Kemendikbud, 2014b).

1. Tena menghubungkan satu bahasan dengan bahasan lainnya, sesuai dengan cara berpikir anak.

2. Tema berfungsi sebagai topik bahasan. Topik bahasan yang dekat dan dikenal anak membuat anak lebih dapat terlibat di dalamnya.

3. Menghubungkan pengetahuan sebelumnya dengan pengetahuan yang baru yang sudah dimiliki anak.

4. Memudahkan pendidik PAUD dalam pengembangan kegiatan belajar sesuai dengan konsep dan sarana yang dimiliki lingkungan.

Berikut contoh tema yang telah ada.

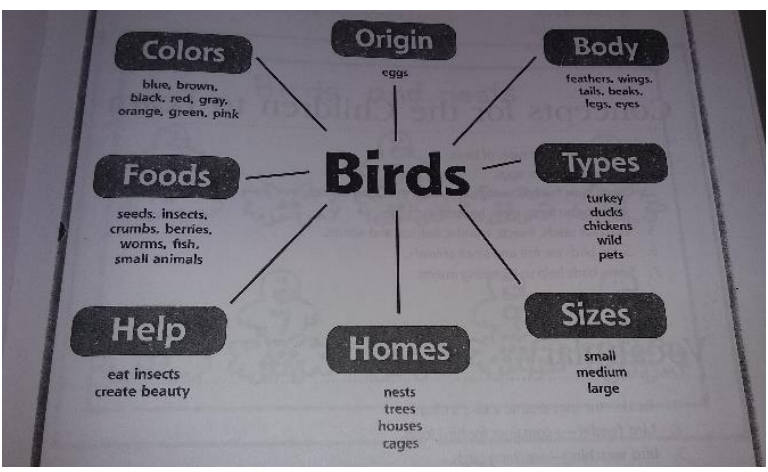

Sumber: Herr \& Larson, 2003:102

\section{Gambar 2. Tema Pembelajaran}

Tema di atas memiliki manfaat yaitu dapat dijadikan sebagai landasan rasional dalam mengembangkan topik pembelajaran yang sesuai dengan karakteristik sekolah. Hal ini senada dengan Permendikbud No. 137 Tahun 2014 yang menyatakan bahwa tema yang disusun perlu memperhatikan kesesuaian dengan karakteristik, kebutuhan, tahap perkembangan anak, dan budaya lokal. Tema yang dikembangkan agar sesuai dengan hal-hal yang dimaksud dalam Permendikbud No. 137 Tahun 2014, maka perlu memperhatikan prinsip-prinsip sebagai berikut (Kemendikbud, 2014a).

1. Kedekatan, artinya tema hedaknya dipilih mulai dari permasalahan dan pengalaman yang terdekat dengan kehidupan anak, misalnya topik tentang anak itu sendiri.

2. Kesederhanaan, artinya tema yang dipilih yang sudah dikenal anak, tidak terlalu sulit untuk dibahas dalam pikiran anak, misalnya mata, bukan panca indera.

3. Kemenarikan, artinya tema yang dipilih harus mampu menarik minat belajar anak, misalnya binatang yang sering dijumpai dalam keseharian anak.

4. Keinsidentalan, artinya pemilihan tema tidak selalu baku yang direncanakan di awal tahun, tetapi juga dapat menyisipkan kejadian luar biasa yang dialami anak, misalnya ketika terjadi erupsi gunung Kelud, maka guru dapat mengangkat topik bencana alam atau gunung sebagai tema pembelajaran di kelasnya.

\section{Budaya}

Kebudayaan berasal dari kata Sansekerta buddayah, yaitu bentuk jamak dari 'budi', yang berarti 'akal'. Koentjaraningrat merumuskan kebudayaan sebagai keseluruhan gagasan dan karya manusia, yang harus dibiasakannya dengan belajar, beserta keseluruhan dari hasil budi dan karyanya itu (Koentjaraningrat, 1997:181). Budaya adalah suatu cara hidup yang berkembang dan dimiliki bersama oleh sebuah kelompok orang dan diwariskan dari generasi ke generasi (Kuper \& Kuper, 2000:199). Jadi, Budaya merupakan cara hidup sebagai hasil dari gagasan dan karya manusia dalam sebuah kelompok masyarakat dan diwariskan turun temurun.

Kebudayaan adalah keseluruhan dari apa yang pernah dihasilkan oleh manusia karena pemikirannya. J. J Honigmann melalui karyanya (Koentjaraningrat, 2000:102) membedakan adanya tiga 'gejala kebudayaan' yaitu (1) ideas, (2) activities, dan (3) artifact, dan ini diperjelas oleh Koentjaraningrat yang mengistilahkannya dengan tiga wujud kebudayaan yaitu: 
1. Wujud kebudayaan sebagai suatu yang kompleks dari ide-ide, gagasangagasan, nilai-nilai, norma-norma, peraturan dan sebagainya.

2. Wujud kebudayaan sebagai suatu kompleks aktivitas serta tindakan berpola dari manusia dalam masyarakat.

3. Wujud kebudayaan sebagai bendabenda hasil karya manusia.

Selanjutnya, mengenai wujud kebudayaan oleh Setiadi (2006:84) memberikan penjelasan sebagai berikut :

1. Wujud Ide

Wujud ide tersebut menunjukkan ide dari kebudayaan, sifatnya abstrak, tak dapat diraba, dipegang ataupun difoto, dan tempatnya ada di alam pikiran warga masyarakat di mana kebudayaan yang bersangkutan itu hidup. Budaya ideal mempunyai fungsi mengatur, mengendalikan, dan memberi arah kepada tindakan, kelakuan dan perbuatan manusia dalam masyarakat sebagai sopan santun. Kebudayaan ideal ini bisa juga disebut adat istiadat. Wujud ide ini misalnya ungah unguh dan teposeliro.

2. Wujud Prilaku

Wujud prilaku dinamakan sebagai sistem sosial, karena menyangkut tindakan dan kelakuan berpola dari manusia itu sendiri. Wujud ini bisa diobservasi, difoto dan didokumentasikan karena dalam sistem sosial ini terdapat aktivitas-aktivitas manusia yang berinteraksi dan berhubungan serta bergaul satu dengan lainnya dalam masyarakat. Bersifat konkret dalam wujud perilaku dan bahasa. Contoh budaya sebagai wujud prilaku adalah kenduren, slametan dan lain-lain.

3. Wujud Artefak

Wujud artefak ini disebut juga kebudayaan fisik, di mana seluruhnya merupakan hasil fisik. Sifatnya paling konkret dan bisa diraba, dilihat dan didokumentasikan. Contohnya: kandang sapi, kuda, ayam, kambing, candi, masjid, musholla, langgar, bangunan pendopo, joglo, limasan, sentong, gapuro, pager, baju batik, lurik, jumputan dan lain sebagainya.
Koenjtaraningrat mengambil sari dari berbagai kerangka yang disusun para sarjana Antropologi, mengemukakan bahwa ada tujuh unsur kebudayaan yang dapat ditemukan pada semua bangsa di dunia yang kemudian disebut unsur-unsur kebudayaan universal, antara lain:

1. Bahasa seperti Bahasa Jawa yang terdiri dari ngoko, kromo andap, kromo madyo, dan kromo inggil.

2. Sistem Pengetahuan yang terdiri dari :

a. alam sekitarnya,

b. tumbuhan yang tumbuh di sekitar daerah tempat tinggal anak,

c. binatang yang hidup di daerah tempat tinggal anak,

d. zat-zat, bahan mentah, dan bendabenda dalam lingkungan anak,

e. tubuh manusia,

f. sifat-sifat dan tingkah laku manusia,

g. ruang dan waktu.

3. Organisasi Sosial. Organisasi sosial yang ada di Yogyakarta antara lain: RT, RW, RK Pedukuhan, dusun kelurahan, kecamatan, kabupaten, propinsi, negara. Ataupun dapat berupa: Paguyuban, komunitas, karang taruna, dasa wisma, PKK, perhimpunan, asosiasi

4. Sistem Peralatan hidup dan Teknologi terdiri dari alat pertukanagan, alat pertanian, alat indudtri tradisional, alat perlautan peraiaran, permainan tradisional

5. Sistem Mata Pencaharian, yang ada di Yogyakarta di antaranya :

a. berburu dan meramu;

b. beternak;

c. bercocok tanam di ladang;

d. menangkap ikan;

e. bercocok tanam menetap dengan sistem irigasi.

Contoh profesi sebagai mata pencaharian adalah buruh, bakul, pegawai, wiraswasta, nelayan, petani, sopir dan lain sebagainya.

6. Sistem Religi seperti sistem kepercayaan, Islam, Kristen, Hindu, Budha, Katholik.

7. Kesenian meliputi : 
a. Tari yang terdiri dari tari klasik, kresi baru, modern, dan kontemporer serta dolanan tradisional,

b. Sandiwara tradisional misalnya ketoprak, srandul, gejog lesung, reog,

c. Musik tradisional contohnya gamelan, hadroh, cokekan, campursari,

d. Seni rupa lukis kanvas, kaca, lukis keramik,

e. Patung kayu, batu, viber,

f. Kerajinan tangan (kriya) dari kulit, daun, kain.

\section{METODE}

Penelitian ini merupakan penelitian kualitatif yang dideskripsikan secara naratif. Sampel dalam penelitian ini adalah 70 orang guru Taman Kanak-kanak se Yogyakarta. Teknik pengumpulan data dengan wawancara, dan dokumentasi. Pengumpulan data awal menggunakan teknik wawancara tidak terstruktur. Teknik dokumentasi untuk mengumpulkan data berupa perencanaan pembelajaran yang telah dibuat guru di sekolah masingmasing. Pengumpulan data awal dilakukan dalam situasi yang tidak dikondisikan secara khusus, namun dilakukan ketika peneliti memberikan pelatihan di beberapa wilayah. Setiap sampel diwawancarai tentang pernah tidaknya guru mengembangkan tema sendiri untuk kelasnya di luar tema-tema yang telah ditentukan dinas dalam kurikulum sebelumnya. Bagi guru yang menjawab pernah, wawancara mendalam dilakukan dengan menanyakan apa tema di luar dinas yang pernah dikembangkan. Pertanyaan selanjutnya adalah tentang pernah dan tidaknya guru mengangkat budaya Yogyakarta sebagai topik untuk dijadikan tema. Pertanyaan terakhir adalah menggali unsur budaya apa yang mungkin dapat digunakan sebagai tema pembelajaran di TK. Dokumentasi merupakan teknik lain yang digunakan untuk mendukung hasil wawancara terkait dengan pengembangan perencanaan pembelajaran untuk anak
Taman Kanak-kanak berupa naskah perencanaan pembelajaran yang telah dirancang guru dalam bentuk Program Semester, Webbing Tema, RPPM, dan RPPH. Teknik analisis data dilakukan secara kualitatif kemudian dilakukan triangulasi data.

\section{HASIL DAN PEMBAHASAN Guru yang pernah mengembangkan tema sendiri}

Hasil penelitian menunjukkan bahwa dari 70 guru Taman Kanak-kanak, hanya 6 orang guru atau $8,5 \%$ guru pernah mengembangkan tema di luar tema yang sudah ditentukan dinas dalam pembelajaran. Tema yang dikembangkan adalah Hari Raya Agama (Idul Fitri dan Idul Adha). Dari 6 orang guru ini hanya 1 orang guru yang pernah mengembangkan tema tentang budaya, yaitu Sekaten. Walaupun jika ditelusuri tema Sekaten merupakan tema Agama juga. Adapun 64 guru TK yang lain mengembangkan tema sesuai dengan tema contoh di kurikulum yaitu tema Diri Sendiri, Lingkunganku, Kebutuhan, Tanaman, Binatang, Alat Komunikasi, Pekerjaan, Rekreasi, Air, Udara, Api, Negaraku, Alam Semesta. Hal ini berarti $91,5 \%$ guru belum mengembangkan tema budaya dalam pembelajaran anak di taman kanak-kanak.

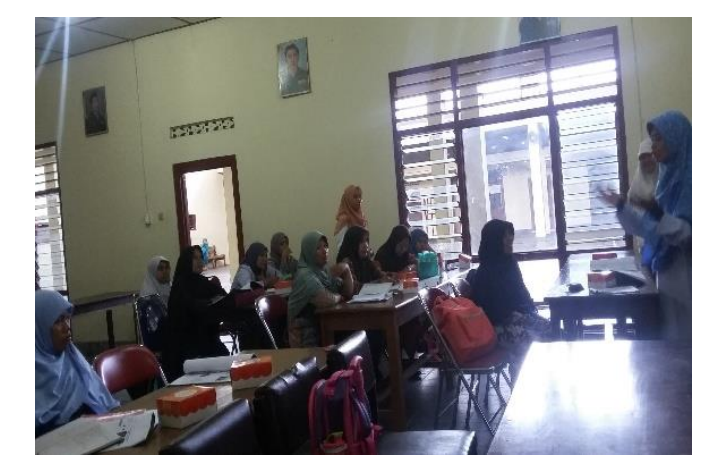

Sumber : Dokumentasi penelitian awal, 2017

Gambar 3. Wawancara Tidak Terstruktur

Guru-guru yang memilih tema budaya dalam pembelajaran untuk anak sudah menyadari prinsip pengembangan tema yaitu tema diambil dari lingkungan terdekat dengan anak. Selain itu, menandai 
hari-hari penting untuk dijadikan dalam tema merupakan salah satu teknik yang dapat dikembangkan untuk pembelajaran. Guru-guru yang memilih tema hari raya keagamaan dan sekaten karena pada bulan tersebut sedang berlangsung acara keagamaan seperti Idul Fitri ataupun Idul Adha. Demikian pula dengan tema sekaten. Di Yogyakarta, sekaten merupakan kegiatan khusus yang dilakukan dalam rangka merayakan hari lahirnya Nabi Muhammad SAW (Maulid). Kedekatan tema tersebut dengan anak memberi peluang untuk dikembangkan sebagai tema pembelajaran dalam kelas.

Adapun beberapa alasan yang disampaikan guru terkait keputusan untuk tidak memilih mengembangkan tema sendiri berbasis budaya karena 1) kurangnya pengetahuan guru untuk mengembangkan tema budaya, 2) tidak adanya pelatihan khusus yang dapat diikuti untuk mengembangkan tema berbasis budaya untuk anak, 3) guru kesulitan dalam mengembangkan tema budaya untuk anak-anak karena terbatasnya biaya dan peralatan sumber belajar yang mendukung, 4) menganggap anak tidak memerlukan pembahasan materi yang mendalam tentang budaya karena sudah sering dijumpai disekitar anak, dan 5) kesulitan dalam mengembangkan rencana pembelajaran berbasis budaya untuk anak dalam bentuk rancangan harian. Alasan tersebut yang menyebabkan perlunya dilakukan penelitian pengembangan terkait dengan perencanaan pembelajaran berbasis budaya lokal. Adapun hasil wawancara dan pengamatan terhadap dokumentasi guru TK terkait beberapa cara guru mengembangkan tema pembelajaran yang pernah dilakukan adalah 1) menggunakan tema yang telah dikembangkan dinas berdasarkan kurikulum sebelumnya, dan 2) melingkari tanggal penting dalam kalender yang mungkin dapat digunakan sebagai tema. Cara-cara yang dilakukan guru sudah terpola dari tahun-tahun yang lalu sehingga untuk mengembangkan tema baru, guru mengalami kesulitan. Kesulitan ini terlihat pula dari ketidakmampuan guru untuk mengembangkan tema baru berbasis budaya sebagai bahan untuk pelatihan pada sosialisasi kurikulum 2013. Hasil penelitian ini kemudian menjadi dasar untuk mengembangkan tema pembelajaran berbasis budaya lokal. Untuk itu, tahap selanjutnya yang akan dilakukan dalam penelitian ini adalah melakukan desain pengembangan tema pembelajaran berbasis budaya lokal, melakukan uji coba, dan diseminasi produk. Berikut salah satu contoh draft hasil workshop pengembangan tema.

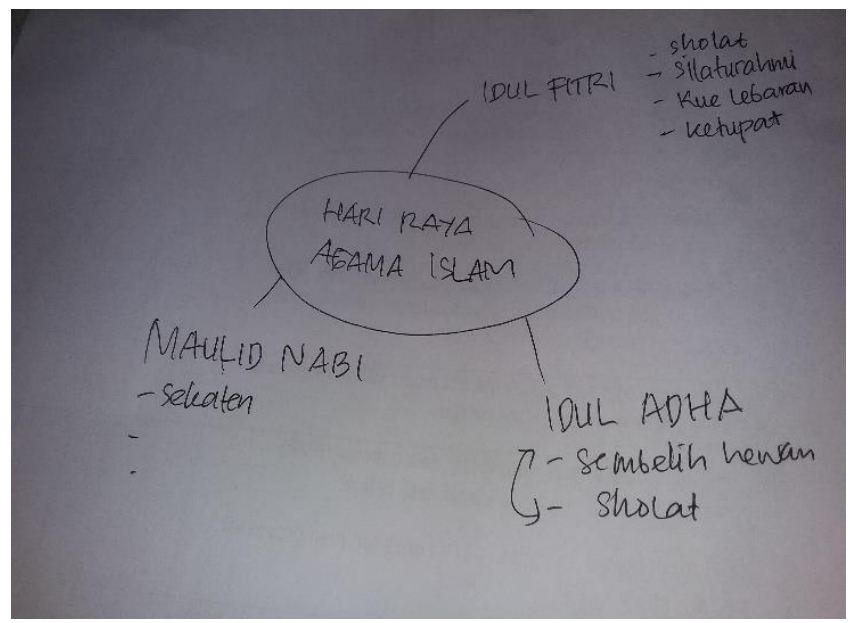

\section{Gambar 4. Hasil Workshop Pengembangan Tema}

\section{PENUTUP}

Sebagian besar guru Taman Kanakkanak se Yogyakarta belum pernah mengembangkan tema pembelajaran berbasis budaya lokal. Guru-guru perlu mendapatkan bimbingan dalam mengembangkan tema-tema tentang budaya. Selain itu, penelitian ini menjadi analisis kebutuhan tentang pengembangan tema pembelajaran kreatif yang dapat dikembangkan oleh peneliti dan guru untuk melibatkan unsur-unsur budaya didalamnya dan sebagai acuan untuk mengembangkan tema pembelajaran berbasis budaya lokal.

\section{DAFTAR PUSTAKA}

Brewer, Jo An. (2007). Introduction to Early Chlidhood Education. USA: Pearson Education, Inc. 
Crain, William. (2007). Teori Perkembangan Konsep dan Aplikasi. Yogyakarta: Pustaka Pelajar.

Essa, Eva L. (2003). Introduction to Early Childhood Education. Canada: Thompson Delmar Learning.

Feeney, Stephanie, Doris Christensen, \& Eva Moravcik. (2006). Who am I in the Live of Children? USA: Pearson Merrill-Prentice Hall.

Herr, Judy \& Larson, Yvonne Libby. (2003). Creative Resources for the Earlychildhood Classroom. USA: Thomson Delmar Learning.

Jackman, Hilda L. (2012). Early Education Curriculum: A Child's Connection to the World, Fifth Edition. USA: Wadworth, Cengage Learning.

Kemendikbud. (2014a). Peraturan Menteri Nomor 137 Tahun 2014. Jakarta: Kemendikbud.

----------------. (2014b). Sosialisasi Kurikulum 2013 PAUD. Jakarta: Kemendikbud.

Koentjaraningrat. (1997). Manusia dan Kebudayaan di Indonesia. Jakarta: Djambatan.

Antropoli.
Offset.

Kuper, Jessica \& Kuper, Adam. (2000). Ensiklopedi Ilmu-ilmu Sosial. Terjamah: Haris Munandar dkk. Jakarta: Raja Grafindo Persada.

Nurani, Yuliani. (2013). Konsep Dasar Pendidikan Anak Usia Dini Edisi 7. Jakarta: Indeks.

Papalia, Diane E., et.al. (2008). Human Development (Psikologi Perkembangan). Jakarta: Kencana.

Rusman. (2012). Model-model Pembelajaran. Jakarta: PT. Rajagrafindo Persada.

Setiadi, Elly M. (2006). Metode, Teori, Teknik Penelitian Kebudayaan: Ideologi, Epistimologi, dan Aplikasi. Yogyakarta: Pustaka Widyatama.

Suyanto, S. (2005). Dasar-dasar Pendidikan Anak Usia Dini. Yogyakarta: Hikayat Publishing.
Anak: Pengenalan dengan Matematika, Sains, Seni, Bahasa, dan Pengetahuan Sosial. Yogyakarta: Hikayat Publishing. 